\title{
Role of Herbal Plants on Autophagy
}

\author{
Susanti Husen ${ }^{1}$, Ronny Lesmana ${ }^{2,3}$, Hanna Goenawan ${ }^{2,3}$, Setiawan ${ }^{2}$ \\ ${ }^{1}$ Magister Program in Biomedical Medical Sciences, Faculty of Medicine, Universitas \\ Padjadjaran, Bandung, Indonesia, ${ }^{2}$ Physiology Division, Department of Biomedical Medical \\ Sciences, Faculty of Medicine, Universitas Padjadjaran, Sumedang, Indonesia, ${ }^{3}$ Physiology \\ Molecular Laboratory, Division of Biological Activity, Central Laboratory, \\ Universitas Padjadjaran, Sumedang, Indonesia
}

\begin{abstract}
Autophagy is a biomolecular system known to play an important role in cell growth, development as well as defense mechanisms, and is also a physiological approach towards homeostasis maintenance. This phenomenon is an intermediary pathway in the pathogenesis and therapy of various disease types, and is currently a new treatment route in the medical world. Hence, it is necessary to deeply understand the regulations, to prepare a treatment strategy in the future. Conversely, there is a high utilization of drugs, in line with the numerous disease cases in the community. Some limited chemical forms have large but necessary side effects, including anticancer agents. The high incidence of resistance and polypharmacy has been implicated in adverse drug interactions, and exorbitant costs, thus the initiative to return back to natural means. Furthermore, herbal medicines have been use in treatments for thousands of years, prior to the discovery of modern medicine. The various types previously studied have been highly beneficial in various disease cases. This review on researches within the last 5 years identified some herbal research articles in the aspect of autophagy, which was then summarized in a table form. Meanwhile, autophagy has been used for cancer therapy, and many plants have the potential to be therapeutic for various diseases through this pathway. Hence, improving related knowledge adds a new dimension to herbal medicine application in the pharmaceutical industry.
\end{abstract}

Keywords: Autophagy, herbal, cancer, metabolic diseases, liver injury, neurological disorder

\section{Peran Berbagai Tanaman Herbal pada Autofagi}

\begin{abstract}
Abstrak
Autofagi adalah sistem biomolekuler sel yang berperan penting dalam pertumbuhan sel, perkembangan dan mekanisme pertahanan, dan merupakan sebuah cara fisiologis untuk mempertahankan homeostasis. Autofagi digunakan sebagai jalur perantara untuk patogenesis dan terapi berbagai jenis penyakit, dan saat ini autofagi telah menjadi jalan pengobatan baru di dunia medis sehingga regulasi jalur autofagi harus dipelajari lebih dalam untuk mempersiapkan strategi pengobatan di masa depan. Di sisi lain, tingginya pemanfaatan obat-obatan sejalan dengan banyaknya kasus penyakit yang muncul di masyarakat. Beberapa obat kimia memiliki efek samping yang besar tetapi jumlahnya terbatas, misalnya pada obat antikanker. Selain itu, tingginya kasus resistensi obat dan polifarmasi menyebabkan interaksi obat yang merugikan dan biaya obat yang tinggi. Oleh karena itu, pengobatan kini telah kembali ke alam. Herbal telah digunakan sebagai pengobatan selama ribuan tahun sebelum pengobatan modern ditemukan. Berbagai jenis herbal telah dipelajari dan memiliki manfaat yang baik dalam berbagai kasus penyakit di masyarakat. Pada artikel review ini, ditelaah artikel-artikel penelitian herbal yang mengambil jalur autofagi dan hasilnya dirangkum dalam bentuk tabel. Studi yang dilakukan dalam kurun waktu 5 tahun terakhir dimasukkan dalam review ini. Sampai sekarang, autofagi telah lebih banyak digunakan untuk terapi kanker dibandingkan yang tanpa kanker. Banyak tanaman herbal yang memiliki potensi untuk menjadi terapi berbagai jenis penyakit melalui jalur autofagi. Pengetahuan tentang autofagi menambah dimensi baru pada pengobatan herbal dan dapat diterapkan dalam industri farmasi.
\end{abstract}

Kata kunci: Autofagi, gangguan metabolisme, gangguan saraf, herbal, kanker, kerusakan hati

Correspondence: dr. Hanna Goenawan, M.Kes., AIFO, PhD., Physiology Division, Department of Biomedical Medical Sciences, Faculty of Medicine, Universitas Padjadjaran, Sumedang, West Java 45363, Indonesia, email: hanna@unpad.ac.id

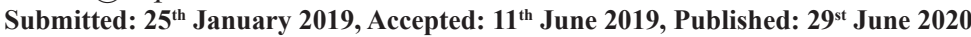




\section{Introduction}

Autophagy is a biomolecular process that occurs at cellular level, where the cell performs an activity consuming its own component which is damaged or malfunctioned, without disturbing cell's function and metabolism. Autophagy is the cell's physiological way to grow, develop, defend themselves, and maintain cell homeostasis. Literally, autophagy comes from Greek, namely "auto" means "self" and "phagein" which means "eat". Until now, researchers are studying about autophagy. Some studies such as in the world of cancer, obesity, metabolic syndrome, alzheimer's, parkinsons, and cardiovascular disease are performed worldwide. ${ }^{1}$

Initially autophagy was known in 1963 by a biochemical researcher from Belgium named Christian de Duve. A single cell can destroy its own components by covering the membrane, forming a kind of bubble sack (autophagosome), then transferring it to the recycling compartment (lysosomes), to be degraded or destroyed. In 1974, Christian de Duve finally received the Nobel Prize for the treatment category for his discovery of lysosomes. In 2016, Professor Yoshinori Ohsumi from Japan received the Nobel Prize for the world category of medicine, for his findings on autophagy. Professor Yoshinori Ohsumi studied the mechanism of autophagy through yeast cells (Saccharomyces cerevisiae) as modeling human cells by making artificial mutations of yeast cells, reducing the production of vacuolar degradation enzymes, and simultaneously stimulating autophagy by starving them. Autophagy is controlled by certain proteins that regulate the regulatory process at the level of initiation and formation of autophagosomes. ${ }^{2,3}$

The autophagy process can provide energy and the recycling process of cell components, as a cell response when facing hunger or other stress. Autophagy can prevent the entry of bacteria and viruses during an infection. Autophagy also contributes to the process of embryo development and cell division. Cells also use autophagy to degrade the damaged proteins and cell organelles, as a control mechanism to resist the risk of aging, as in sarcopenia. $^{4}$

There are three types of autophagy, namely: macro-autophagy, micro-autophagy, and autophagy chaperone-mediated (CMA). Macro-autophagy is a process to carry the cytoplasmic component to the lysosome through an intermediate double membrane of vesicles, referred to as the autophagosome. In contrast, the cytosolic component is directly taken by the lysosome itself through invagination of the lysosome membrane. Macro and micro-autophagy ingest large structures through selective and non-selective mechanisms. Autophagy chaperone-mediated (CMA) which is a protein translocated across membrane lysosomes in a complex with a companion protein that is recognized by membrane protein lysosomes, resulting in folds and degradation. ${ }^{5}$

Autophagy plays an important role in tumor development, cell death and living metabolism. Autophagy is induced in response to chemotherapy treatments and as an important mechanism for drug resistance. Autophagy has been recognized as a potential target for cancer therapy. This is evidenced by various studies, one of which is the potential of mefloquine to produce anticancer effects on breast cancer cells. ${ }^{6}$

In the cancer's research, autophagy can act as a suppressor or promoter. As a suppressor, autophagy plays an important role to increase oxidative stress, genome instability, and activation of DNA damage responses. Cancer cells also depend on autophagy for survival, due to tumor dependence on the supply of nutrients for the maintenance of rapid cell proliferation. Often, cellular processes such as apoptosis and inflammation are associated 
with various type of disease in the hope that autophagy can look for potential biomarkers or drug targets. ${ }^{7}$ Many studies of autophagy are engaged in non-cancer field, such as neurodegenerative (Parkinson's disease, alzheimer's), metabolic syndrome, sarcopenia, cardiovascular disease, and so on. Therefore, the autophagy process can play a role in various types of diseases.

Herbal medicine has been used as a treatment for thousands of years, before modern medicine was discovered. Herbals medicine are a mixture of natural ingredients without addition of synthetic chemicals. Herbal plants can have various functions in the body's metabolism such as antipyretic, analgesic, neuroprotective, sedative, antiinflammatory, anti-cancer, and immune modulatory. The mechanism of action of herbal plant molecules shows that plant miRNA in food can regulate the expression of target genes in humans. Some studies define miRNA as an intermediary for herbal plants with disease processes in the body. ${ }^{8}$ At present, herbals medicine are widely used by the community as a self-medication. Parts of the plant that can be used including roots, stems, leaves, tubers or anotherparts of the plant. If it has been processed and processed in such a way, herbal plants (herbal medicines) can have therapeutic benefits. The increase of public interest in herbal plants has spurred the pharmaceutical industry to produce herbal medicines. However, there are lack scientific evidence regarding the benefits of these herbal medicine.

\section{Methods}

The articles selection process was an extensive search in electronic databases, i.e., PubMed and Google search engine for articles written in English. The keywords "herbal" and "autophagy" were used in the search. We identify clinical studies done between 2014 and 2019, on autophagy and herbal treatment.

\section{Results}

The search resulted in 100 articles, and 20 articles met the requirements and included in the review. Data source explained the herbals medicine in Table 1.

\section{Discussion}

Various types of herbal medicine have potential activity to induce autophagy process inside the cells. In the case of non-alcoholic fatty liver disease (NAFDL), Lyciumbarbarum polysaccharides (LBPs) treatment in cell culture can increase autophagic markers (Atg5 and LCIII) and decrease autophagy inhibitor (phosphorylated (p) mTOR and p62). Rat obesity, insulin resistance, liver injury (inflammatory focus and cellular necrosis), oxidative stress (CAT antioxidant enzymes and GPx) also increased. Autophagy can protect self-digestion of intracellular organelles, including lipid droplets (lipophagy) and lipid degradation besides lipolysis. ${ }^{9}$

Harmine in the case of endocrine disorders could induce autophagy and apoptosis by inhibiting Akt/mTOR pathway in B16 cells. B16 cells are murine tumor cell lines used for the study of metastases as models for human skin cancer. The autophagosome formation was stimulated by LC3-II added damage and p16 degeneration in B16 cells, which showed autophagy induction. Cell death and sub-G2 population showed that harmine can cause cell death. In particular, 3-MA, an autophagy inhibitor by inhibiting the cycle of cell cycle prevention and arrest, which indicates that autophagy is important for cell death. In addition, the results show that damage can be inhibited from the AKT and mTOR, which can mediate autophagy. ${ }^{10}$

Curcuma longa in the case of acute myocardial infarction suppresses autophagy 
Table 1 Mechanisms and Herbal Medicine Compounds that Have Autophagy Activity

\begin{tabular}{|c|c|c|c|c|c|c|}
\hline No & Name & Cases & Compound & Author & Years & Country \\
\hline 1 & Wolfberry & $\begin{array}{l}\text { Non-Alcoholic } \\
\text { Fatty Liver Disease } \\
\text { (NAFLD) }\end{array}$ & $\begin{array}{l}\text { Lycium barbarum } \\
\text { polysaccharides }\end{array}$ & Cong Liu, Jia-Zhi Liao, Pei-Yuan Li & 2017 & China \\
\hline 2 & $\begin{array}{l}\text { Muniziqi } \\
\text { Granule }\end{array}$ & $\begin{array}{l}\text { Endocrine Disorder } \\
\text { and Anticancer }\end{array}$ & Peganum Harmala & $\begin{array}{l}\text { Nan Zou, Yue Wei, Fenghua Li, Yang Yang, Xuemei } \\
\text { Cheng and Changhong Wang }\end{array}$ & 2017 & China \\
\hline 3 & Curcuma longa & $\begin{array}{l}\text { Acute Myocardial } \\
\text { Infarction }\end{array}$ & Curcumin & $\begin{array}{l}\text { Zhouqing Huang, Bozhi Ye, Zhenyu Dai, Xinlei Wu, } \\
\text { Zhongqiu Lu, Peiren Shan And Weijian Huang }\end{array}$ & 2014 & China \\
\hline 4 & Ginseng & Colorectal Cancer & Protopanaxadiol (PPD) & $\begin{array}{l}\text { Hong Ri Jin, Charles H Du, Chong-Zhi Wang, Chun-Su } \\
\text { Yuan, Wei Du }\end{array}$ & 2018 & $\begin{array}{l}\text { United } \\
\text { States }\end{array}$ \\
\hline 5 & $\begin{array}{l}\text { Paeonia } \\
\text { suffruticosa root } \\
\text { bark }\end{array}$ & Pancreatic Cancer & $\begin{array}{l}\text { Paeonol (Pae), Paeoniflorin } \\
\text { (PF), Gallic Acid (GA), } \\
\text { and Penta-O-Galloyl-B-D- } \\
\text { Glucose Hydrate (5GG) }\end{array}$ & $\begin{array}{l}\text { Yu-Huei Liu, Yui-Ping Weng, Hsin-Ying Tsai, Chao- } \\
\text { Jung Chen, Der-Yen Lee, Ching-Liang Hsieh, Yang- } \\
\text { Chang Wu, Jung-Yaw Lin }\end{array}$ & 2018 & China \\
\hline 6 & Ginkgo biloba & Alzheimer's Disease & $\begin{array}{l}\text { Ginkgolide A, Bilobalide, and } \\
\text { Flavonoids }\end{array}$ & $\begin{array}{l}\text { Qin Yiren, Zhang Yu, Tomic Inge, Hao Wenlin, Menger } \\
\text { Michael D, Liu Chunfeng, Fassbender Klaus, Liu, Yang }\end{array}$ & 2018 & Germany \\
\hline 7 & $\begin{array}{l}\text { Uncaria } \\
\text { rhynchophylla }\end{array}$ & Parkinson's Disease & $\begin{array}{l}\text { 6-hydroxydopamine } \\
\text { (6-OHDA) }\end{array}$ & $\begin{array}{l}\text { Yu-Long Lan, Jun-Jun Zhou, Jing Liu, Xiao-Kui Huo, } \\
\text { Ya-Li Wang, Jia-Hao Liang, Jian-Chao Zhao, Cheng- } \\
\text { Peng Sun, Zhen-Long Yu, Lin-Lin Fang, Xiang-Ge } \\
\text { Tian, Lei Feng, Jing Ning, Bao-Jing Zhang, Chao Wang, } \\
\text { Xin-Yu Zhao, Xiao-Chi Ma }\end{array}$ & 2018 & China \\
\hline 8 & $\begin{array}{l}\text { Raphanus } \\
\text { sativus }\end{array}$ & Lymphoma & Sulforaphene (LFS-01) & $\begin{array}{l}\text { Haina Wang, Fuqiang Wang, Sijin Wu, Zhiheng Liu, } \\
\text { Tingting Li, Lei Mao, Jie Zhang, Cheng Li, Caigang } \\
\text { Liu, Yongliang Yang }\end{array}$ & 2018 & China \\
\hline 9 & $\begin{array}{l}\text { Astragali } \\
\text { Mongolici }\end{array}$ & Graves' Orbitopathy & Astragaloside IV & $\begin{array}{l}\text { Hong Li, Yali Zhang, Jie Min, Long Gao, Ren Zhang, } \\
\text { Yucheng Yang }\end{array}$ & 2017 & China \\
\hline 10 & $\begin{array}{l}\text { Polygonum } \\
\text { cuspidatum }\end{array}$ & $\begin{array}{l}\text { Ischemic Heart } \\
\text { Diseases }\end{array}$ & Resveratrol & $\begin{array}{l}\text { Dawei Wang, Weiqing Yu, Yuntao Liu, Guofu Zhong, } \\
\text { Zhen Zhao, Xia Yan, and Qing Liu }\end{array}$ & 2017 & China \\
\hline 11 & $\begin{array}{l}\text { Radix } \\
\text { Stephaniae } \\
\text { tetrandrae }\end{array}$ & Breast Cancer Cells & Tetrandrine & $\begin{array}{l}\text { Vincent Kam Wai Wong, Wu Zeng, Juan Chen, Xiao } \\
\text { Jun Yao, Elaine Lai Han Leung, Qian Qian Wang, } \\
\text { Pauline Chiu, Ben C. B. Ko4 and Betty Yuen Kwan } \\
\text { Law }\end{array}$ & 2017 & China \\
\hline
\end{tabular}


Table 1 Mechanisms and Herbal Medicine Compounds that Have Autophagy Activity (continued)

\begin{tabular}{|c|c|c|c|c|c|c|}
\hline No & Name & Cases & Compound & Author & Years & Country \\
\hline 12 & $\begin{array}{l}\text { Pogostemon } \\
\text { cablin }\end{array}$ & Colorectal Carcinoma & Pogostone & $\begin{array}{l}\text { Zhi-Xing Cao, Yu-Ting Yang, Si Yu, Yu-Zhi Li, Wen- } \\
\text { Wen Wang, Jing Huang, Xiao-Fang Xie, Liang Xiong, } \\
\text { Song Lei, Cheng Peng }\end{array}$ & 2016 & China \\
\hline 13 & $\begin{array}{l}\text { Glycyrrhiza } \\
\text { uralensis Fisch. }\end{array}$ & Lung Cancer & Licochalcone A & $\begin{array}{l}\text { Zheng-Hai Tang, Xin Chen, Zhao-Yu Wang, Ke Chai, } \\
\text { Ya-Fang Wang, Xiao-Huang Xu, Xiao-Wen Wang, Jia- } \\
\text { Hong Lu, Yi-Tao Wang, Xiu-Ping Chen \& Jin-Jian Lu }\end{array}$ & 2016 & China \\
\hline 14 & $\begin{array}{l}\text { Gnetum } \\
\text { cleistostachyum }\end{array}$ & Bladder Cancer & Isorhapontigenin & $\begin{array}{l}\text { Yuguang Liang, Junlan Zhu, Haishan Huang, Daimin } \\
\text { Xiang, Yang Li, Dongyun Zhang, Jingxia Li, Yulei } \\
\text { Wang,Honglei Jin, Guosong Jiang, Zeyuan Liu, and } \\
\text { Chuanshu Huang }\end{array}$ & 2016 & China \\
\hline 15 & Nutmeg & Sarkopenia & Macelignan & $\begin{array}{l}\text { Yuni Susanti Pratiwi, Ronny Lesmana, Hanna } \\
\text { Goenawan, Nova Sylviana, Iwan Setiawan, Vita } \\
\text { Murniati Tarawan, Keri Lestari, Rizky Abdulah, } \\
\text { Lazuardhi Dwipa, Ambrosius Purba, and Unang } \\
\text { Supratman }\end{array}$ & 2018 & Indonesia \\
\hline 16 & $\begin{array}{l}\text { Sigesbeckia } \\
\text { orientalis }\end{array}$ & Rheumatoid Arthritis & $\begin{array}{l}\text { Pimarenoids and } \\
\text { Sequiterpenes. }\end{array}$ & $\begin{array}{l}\text { Qian Ru Zhang, Zhang Feng Zhong, Wei Sang, Wei } \\
\text { Xiong, Hong Xun Tao, Guan Ding Zhao, Zhi Xin Li, } \\
\text { Qiu Shuo Ma, Anfernee Kai Wing Tse, Yuan Jia Hu, } \\
\text { Hua Yu, Yi Tao Wang }\end{array}$ & 2019 & China \\
\hline 17 & $\begin{array}{l}\text { Murraya } \\
\text { koenigii }\end{array}$ & $\begin{array}{l}\text { Oral Squamous Cell } \\
\text { Carcinoma (OSCC) }\end{array}$ & Carbazole Alkaloids & $\begin{array}{l}\text { Tanyarath Utaipan, Anan Athipornchai, Apichart } \\
\text { Suksamrarn, Canussanun Jirachotikoon, Xiaohong } \\
\text { Yuan, Monthon Lertcanawanichakul, Warangkana } \\
\text { Chunglok }\end{array}$ & 2016 & Japan \\
\hline 18 & $\begin{array}{l}\text { Nelumbo } \\
\text { nucifera } \\
\text { Gaertn. }\end{array}$ & Melanoma & 7-Hydroxydehydronuciferine & $\begin{array}{l}\text { Pei-Fang Wu, Chien-Chih Chiu, Chung-Yi Chen and } \\
\text { Hui-Min David Wang }\end{array}$ & 2015 & Taiwan \\
\hline 19 & Aster tataricus & Hepatotoksis & CyclopeptideAstin B & $\begin{array}{l}\text { Li Wang, Ming-Dan Li, Pei-Pei Cao, Chao-Feng } \\
\text { Zhang, Fang Huang, Xiang-Hong Xu, Bao-Lin Liu, } \\
\text { Mian Zhang }\end{array}$ & 2014 & China \\
\hline 20 & $\begin{array}{l}\text { Bupleurum } \\
\text { chinense }\end{array}$ & Fever and Chill & Saikosaponins & $\begin{array}{l}\text { Betty Yuen-Kwan Law, Jing-Fang Mo and Vincent } \\
\text { Kam-Wai Wong }\end{array}$ & 2014 & China \\
\hline
\end{tabular}


(LC3B II / LC3B I ratio) in H9c2 myocytes and increases cell survival. ${ }^{11}$ Ginseng plants containing protopanaxadiol (PPD) can increase cell death by inhibiting autophagy or suppressing Mcl-1, inhibiting gene expression involved in fatty acid biosynthesis and cholesterol and inducing synergistic cancer cell death with cerulentine fatty acid synthase inhibitors. In addition, PPD can directly suppress ER and cause lipid imbalance. ${ }^{12}$

In the case of pancreatic cancer, Paeonia suffruticosa (PS) can stimulate the endoplasmic reticulum stress to affect the mitochondrial membrane thereby increasing the amount of autophagosome, inhibiting their degradation, inducing autophagy and cell apoptosis. In addition, a decrease in proteostasis by PS causes changes in the actin cytoskeleton, decreased cell motility, and disrupts the development of the cell cycle. In contrast, scavengers of ROS partially reverse the degradation of peptidyl-prolyl cis-trans isomerase B (PPIB) through a portion of PS, ER protein for protein folding, indicating that the production of ROS by PS becomes the end of mitophage PS and end of cell apoptosis. However, administering oral PS alone or in combination with an anticancer drug gemcitabine can inhibit tumor growth in xenograft models without affecting body weight. ${ }^{13}$

Gingko biloba can be used to treat alzheimer's cases. Gingko biloba extract elicit protective tau protein ( $\mathrm{p}$-Tau) through the autophagy-lysosomal pathway and reduces cerebral p-Tau level and prevents alzheimer diseases pathogenesis. p-Tau accumulated in the mouse brain, when the key autophagic component, ATG7, was ablated in the forebrain neurons. Autophagy-enhancing interventions decreased the protein level of cerebral p-Tau in the tau-transgenic mouse brain. The cerebral p-Tau was decreased and the cognitive deficit was attenuated. ${ }^{14}$

Uncaria rhynchophylla extract (URE) inhibits HSP90 expression and reverses apoptosis and autophagy cells by inducing $\mathrm{MPP}+$ and increases expression of $\mathrm{Bcl}-2$, Cyclin D1, p-ERK, p-PI3K p85, PI3K p110 $\alpha$, p-AKT, and LC3-I and reduce caspase 3, Bax, p-JNK, p-p38, and LC3-II. URE can reduce the apoptosis ratio and increase the transmembrane potential of mitochondria. So that URE therapy can improve Parkinson's disease and behavioral disorders. ${ }^{15}$

Lymphoma can be treated with sulforaphene (LFS-01). LFS-01 is the main chemical element of Raphanus sativus. LFS-01 inhibits the mTOR pathway by inhibiting AMPK which can damage mediated mitophages. Assembling apoptotic vacuoles and autophagy at LFS01 exposure to maintain Nrf2 in the nucleus has an effect on increasing regulation of p62/ SQSTM1, an important structural component of autophagosomes during the mitophagic process. In addition, the Transcriptomy study confirmed that 15 autophagy-related genes such as p62/SQSTM1, VCP and BCL2 were differently expressed after LFS-01 treatment. So, LFS-01 triggers mitophagic cell death through p62 over expression mediated by AMPK activation. ${ }^{16}$

Other herbal medicine is Radix Astragali Mongolici, containing the main active ingredient is Astragaloside IV (AS-VI) which has the potential to treat Graves' orbitopathy (GO). AS-IV can stimulate inflammatory cytokine mRNA expression interleukin (IL)$1 \beta$, IL-6, IL-8, TNF- $\alpha$, and MCP-1) in cultured orbital fibroblasts. The increase in inflammatory cytokines using the expression Beclin-1 and Agt-5 and the conversion of LC3-I to LC3II was induced by an increase in autophagy activity thereby increasing autophagy, as well. Pretreatment with autophagy 3-MA and bafilomycin A1 inhibitors, or silencing proteins related to autofagy Beclin- 1 and Atg5 , prevents inflammation of IL- $1 \beta$-induced orbital fibroblasts, while pretreatment with rapamycin autofagy activator has the opposite 
effect. These data indicate that autophagy is involved in the inflammation of GO orbitals. ${ }^{17}$

Autophagy in ischemic heart diseases inhibiting atherosclerosis progression and reducing cell death during the ischemic phase. Crucial role of adenosine monophosphateactivated protein kinase (AMPK) induced autophagy in maintaining cellular homeostasis under conditions of energy deprivation. AMPK is a sensitive indicator of cellular energy status through the detection of decreased ATP and a high ratio of AMP/ATP. In the context of myocardial ischemia, AMPK is activated by low ATP, further inducing the subsequent autophagy. Emerging evidence indicates that AMPK modulates the initiation of autophagy. Moreover, another signaling pathway through which AMPK phosphorylates Beclin-1 and then induces the Beclin-1-VPS34-VPS15 complex (PI3K complex) to promote the initiation of autophagy. Low dose resveratrol improved survival both in $\mathrm{H} 9 \mathrm{c} 2$ cardiac myoblast cells and in the rat myocardium in response to $\mathrm{I} / \mathrm{R}$ injury. Resveratrol may play a beneficial role in reversing remodeling of the myocardium after infarction through promoting autophagic activity mediated by enhancement of the AMP kinase pathway. ${ }^{18}$

Tetrandrine (Tet) from Radix Stephaniae tetrandrae, can stimulate increased the flux and autophagic formation of autofagosomes in breast cancer cells. Tetrandrine induces autophagy by inactivating mTOR and calcium/ calmodulin-dependent protein kinase kinase-b (CaMKK-b), 5' AMP-activated protein kinase (AMPK) independently. ${ }^{19}$ In other cancer cases, pogostone as an important ingredient of pogostemon cablin has bioactivity as anti-colorectal tumor property by inducing autophagy and apoptosis in the human colorectal cancer cells. Pogostone induces autophagy and apoptosis by reducing AKT/ mTOR phosphorylation and by regulating the expression of LC3-II, caspase-7 and caspase- $3 .^{20}$
Licochalcone A (LCA) is a flavonoid isolated from Glycyrrhiza uralensis Fisch. LCA has an anti-cancer effect on small cell lung cancer cells (NSCLC) by reducing cell viability, increasing the release of lactic dehydrogenase, and stimulating apoptosis and autophagy. After treatment with LCA there was an increase in the expression of modification of the protein 3 chain associated with phosphatidletanolamine protein-related microtubules (LC3-II) and the formation of punta GFP-LC3, two markers of autophagi. In addition, LCA increases protein expression related to endoplasmic reticulum stress, such as binding of immunoglobulin proteins and homologous $\mathrm{C} / \mathrm{EBP}$ (CHOP) proteins. ${ }^{21}$

Isorhapontigenin (ISO) isolated from Gnetum cleistostachyum, induced autophagy and inhibit bladder cancer growth through MAPK8-JUN dependent transcriptional induction of SESN2. ${ }^{22}$ Pala (nutmeg) in the case of sarcopenia is useful for improving and maintaining muscle mass by inhibiting autophagy activity. Nutmeg can increase levels of serine protein/threonine kinase (AKT), activation of rapamycin (mTOR) mammal targets, stimulate myogenesis, regeneration processes, and maintain muscle mass through the IGF-AKT-mTOR pathway. In addition, nutmeg can prevent reduced muscle wasting in the soleus muscle by inhibiting autophagy activity during aging. ${ }^{23}$

Chronic inflammation and joint damage in RA can be overcome through autophagy which regulates apoptotic resistance and hyperplasia in synovial fibroblasts so that it induces osteoclast-mediated bone resorption through citrullinated peptide transport to the MHC compartment. RASFs show apoptotic resistance was associated with autophagy induction by increasing ATG expression in Beclin1 and LC3 conversion in response to ER pressure. Increased levels of autophagy in RASFs correlate with a decrease in CCAAT /enhancer binding protein and homologous 
protein level (CHOP) compared to $\mathrm{OA}$ synovial fibroblast (OASFs). ${ }^{24,25}$

Leaf $M$. koenigii has the properties of chemotherapeutic agents namely mahanine and isomahanine, by inducing apoptosis and stimulating the expression of autophagosome marker microtubules associated with protein 1 light chain 3, type II (LC3B-II). Both carbazole alkaloids caused an increase in accumulation of p62/sequestosome1 (p62/ SQSTM1), with LC3B-II expression and caspase-3 cleasing thus inhibiting autofagic flux. Therefore, M. koenigii leaves can be used as anticancer therapy for OSCC (oral squamous cell carcinoma cells) cases. ${ }^{26}$

7-hydroxydehydronuciferine (7-HDNF) isolated from Nelumbo nucifera Gaertn. leaves, is useful as an anticancer by inhibiting the growth of melanoma tumors in vivo and in vitro. The 7-HDNF effect through the process of autophagocytosis and Acidic Vesicular Organelles (AVO) as an autophagy marker was observed by staining the lysosomotropic agent. The autophagy response was eligible by LC3-II and ATG induction, followed by detection of AVO formation and LC3-II recruitment processed into autophagosomes. ${ }^{27}$

Aster tataricus from Siberia grows on well drained soil under full sun. Plants can spread aggressively with rhizomes in optimal growth conditions. Astins (including astin B) isolated from Aster tataricus, showed hepatotoxic properties in vivo and in vitro studies. In L-02 cells, autophagy is characterized by acid-vesicular fluorescence, increases LC3-II and decreases p62 expression. Autophagy is further supported by increased cytotoxicity and caspase- 3 splitting after treatment with caspase inhibitors. ${ }^{28}$

The last medicinal herbal plant is Chaihu, which is from the dried root of Bupleurum chinense DC. Chaihu has an active component of saikosaponins which acts as an immune module, antiviral, antipyretic, hepatoprotective, anticancer, sedative, and an analgesic effect.
Saikosaponin suppresses the production of cyclic adenosine monophosphate (c-AMP) in the hypothalamus and stimulates the release of antipyretic substances. Saikosaponin also has a strong anti-endotoxin effect by reducing the increase in body temperature. This can occur because of cellular homeostasis regulated by autophagy. ${ }^{29}$

\section{Conclusion}

Autophagy plays a role in keeping the body healthy and prime with herbal medicine. Autophagy can be likened to a cell recycling plant that is in our body that provides great benefits. If there is no autophagy, our body will be filled with garbage from the body's own cells. However, further research is needed to study the biomolecular effects of oral herbal medicine on cell function and metabolism. The knowledge about autophagy adds a new dimension to herbal medicine and can be applied in the pharmaceutical industry.

\section{Funding}

This literature review was supported by Universitas Padjadjaran and funded by The Indonesian Ministry of Research, Technology, and Higher Education for Grant-in-Aid PUPT (Program Unggulan Perguruan Tinggi, 3670/ UN.6.C/LT/2018) 2018 to Ronny Lesmana.

\section{Conflict of Interest}

All the authors have agreed on the paper's contents. The authors have no conflict of interest.

\section{References}

1. Nakatogawa H, Suzuki K, Kamada Y, Ohsumi Y. Dynamics and diversity in autophagymechanisms: Lessons from yeast. Nat Rev Mol Cell Biol. 2009;10: 
458-68. doi: 10.1038/nrm2708

2. Sedwick C. Yoshinori Ohsumi: Autophagy from beginning to end. J Cell Biol. 2012; 197(2):164-5. doi: 10.1083/jcb.1972pi

3. Nakatogawa H, Ishii J, Asai E, Ohsumi Y. Atg4 recycles inappropriately lipidated Atg 8 to promote autophagosome biogenesis. Autophagy. 2012;8(2):177-86. doi: 10.4161/auto.8.2.18373

4. Jiao J, Demontis F. Skeletal muscle autophagy and its role in sarcopenia and organismal aging. Curr Opin Pharmacol. 2017;34:1-6. doi: 10.1016/j.coph.2017.0 3.009

5. Glick D, Barth S, Macleod K.F. Autophagy: Cellular and molecular mechanisms. J Pathol. 2010;221(1):3-12. doi: 10.1002/path.2697

6. Sharma N, Thomas S, Golden EB, Hofman FM, Chen TC, Petasis NA, et al. Inhibition of autophagy and induction of breast cancer cell death by mefloquine, an antimalaria agent. Cancer Lett. 2012: 326(2):143-54. doi: 10.1016/j.canlet.201 2.07 .029

7. Morselli E, Galluzzi L, Kepp O, Vicencio JM, Crriollo A, Maiuri MC, et al. Anti- and pro-tumor functions of autophagy. Biochim Biophys Acta. 2009; 1793(9):1524-32. doi: 10.1016/j.bbamcr. 2009.01.006

8. Sala-Cirtog M, Marian C, Anghel A. New insights of medicinal plant therapeutic activity-The miRNA transfer. Biomed Pharmacother. 2015;74:228-32. doi: 10.1 016/j.biopha.2015.08.016

9. Liu C, Liao JZ, Li PY. Traditional chinese herbal extracts inducing autophagy as a novel approach in therapy of nonalcoholic fatty liver disease. World J Gastroenterol. 2017;23(11):1964-73. doi: 10.3748/wjg. v23.i11.1964

10. Zou N, Wei Y, Li F, Yang Y, Cheng $\mathrm{X}$, Wang $\mathrm{C}$. The inhibitory effects of compound Muniziqi granule against B16 cells and harmine induced autophagy and apoptosis by inhibiting Akt/mTOR pathway. BMC Complement Altern Med. 2017;17(1):517-23. doi: 10.1186/s12906 -017-2017-4

11. Huang Z, Ye B, Dai Z, Wu X, Lu Z, Shan $P$, et al. Curcumin inhibits autophagy and apoptosis in hypoxia/reoxygenationinduced myocytes. Mol Med Rep. 2015; 11(6):4678-84. doi: 10.3892/mmr.2015.3 322

12. Jin HR, Du CH, Wang CZ, Yuan CS, Du W. Ginseng metabolite protopanaxadiol interferes with lipid metabolism and induces endoplasmic reticulum stress and $\mathrm{p} 53$ activation to promote cancer cell death. Phytother Res. 2019;33(3):610-7. doi: 10.1002/ptr.6249

13. Liu YH, Weng YP, Tsai HY, Chen CJ, Lee DY, Hsieh CL, et al. Aqueous extracts of paeonia suffruticosa modulates mitochondrial proteostasis by reactive oxygen species-induced endoplasmic reticulum stress in pancreatic cancer cells. Phytomedicine. 2018;46:184-92. doi: 10. 1016/ j.phymed.2018.03.037

14. Qin Y, Zhang Y, Tomic I, Hao W, Menger MD, Liu C, et al. Ginkgo biloba extract egb 761 and its specific components elicit protective protein clearance through the autophagy-lysosomal pathway in tautransgenic mice and cultured neurons. J Alzheimers Dis. 2018;65(1):243-63. doi: 10.3233/JAD-180426

15. Lan YL, Zhou JJ, Liu J, Huo XK, Wang YL, Liang JH, et al. Uncaria rhynchophylla ameliorates parkinson's disease by inhibiting hsp90 expression: Insights from quantitative proteomics. Cell Physiol Biochem. 2018;47(4):145364. doi: 10.1159/000490837

16. Li H, Zhang Y, Min J, Gao L, Zhang $\mathrm{R}$, Yang Y. Astragaloside IV attenuates orbital inflammation in graves' orbitopathy through suppression of autophagy. Inflamm 
Res. 2018;67(2):117-27. doi: 10. 1007/s0 0011-017-1100-0

17. Wang D, Yu W, Liu Y, Zhong G, Zhao Z, Yan $X$, et al. Roles of autophagy in ischemic heart diseases and the modulatory effects of chinese herbal medicine. Am J Chin Med. 2017;45(7):1401-19. doi: 10.1142/ S0192415X17500768

18. Wong VKW, Zeng W, Chen J, Yao XJ, Leung ELH, Wang QQ, et al. Tetrandrine, an activator of autophagy, induces autophagic cell death via PKC- $\alpha$ inhibition and mTOR-dependent mechanisms. Front Pharmacol. 2017;8:351-4. doi: 10.3389/ fphar.2017.00351

19. Cao ZX, Yang YT, Yu S, Li YZ, Wang WW, Huang J, et al. Pogostone induces autophagy and apoptosis involving $\mathrm{PI} 3 \mathrm{~K} / \mathrm{Akt} / \mathrm{mTOR}$ axis in human colorectal carcinoma HCT116 cells. J Ethnopharmacol. 2017;202:20-7. doi: 10. 1016/j.j ep.2016.07.028

20. Tang ZH, Chen X, Wang ZY, Chai K, Wang $\mathrm{YF}, \mathrm{Xu} \mathrm{XH}$, et al. Induction of $\mathrm{C} / \mathrm{EBP}$ homologous protein-mediated apoptosis and autophagy by Licochalcone A in non-small cell lung cancer cells. Sci Rep. 2016;6:262241. doi: 10.1038/srep26 241

21. Liang Y, Zhu J, Huang H, Xiang D, Li Y, Zhang D, et al. SESN2/Sestrin 2 inductionmediated autophagy and inhibitory effect of Isorhapontigenin (ISO) on human bladder cancers. Autophagy. 2016;12(8):1229-39. doi: 10.1080/15548627.2016.1179403

22. Pratiwi YS, Lesmana R, Goenawan $\mathrm{H}$, Sylviana N, Setiawan I, Tarawan $\mathrm{VM}$, et al. Nutmeg extract increases skeletal muscle mass in aging rats partly via IGF1-AKT-mTOR pathway and inhibition of autophagy. Hindawi. Evid
Based Complementary Altern Med. 2018: 2810840. doi: 10.1155/2018/2810840

23. Zhang QR, Zhong ZF, Sang W, Xiong W, Tao HX, Zhao GD, et al. Comparative comprehension on the anti-rheumatic chinese herbal medicine Siegesbeckiae Herba: combined computational predictions and experimental investigations. J Ethnopharmacol. 2019;228:200-9. doi: 10. 1016/j.jep.2018.09.02 3

24. Dai, Y, Hu S. Recent insights into the role of autophagy in the pathogenesis of rheumatoid arthritis. Rheumatology (Oxford). 2016;55(3):403-10. doi: 10.10 93/rheumatology/kev337

25. Utaipan T, Athipornchai A, Suksamrarn A, Jirachotikoon C, Yuan X, Lertcanawanichakul $\mathrm{M}$, et al. Carbazole alkaloids from Murraya koenigii trigger apoptosis and autophagic flux inhibition in human oral squamous cell carcinoma cells. J Nat Med. 2017;71(1):158-69. doi: 10.10 07/s11418-016-1045-6

26. Wu PF, Chiu CC, Chen CY, Wang HM. 7-Hydroxydehydronuciferine induces human melanoma death via triggering autophagy and apoptosis. Exp Dermatol. 2015;24(12):930-5. doi: 10.1111/exd.128 05

27. Wang Li, Li MD, Cao PP, Zhang CF, Huang F, Xu XH, et al. Astin B, a cyclic pentapeptide from Aster tataricus, induces apoptosis and autophagy in human hepatic L-02 cells. Chem Biol Interact. 2014;223: 1-9. doi: 10.1016/j.cbi.2014.09.003

28. Law BY, Mo JF, Wong VK. Autophagic effects of Chaihu (dried roots of Bupleurum Chinense DC or Bupleurum Scorzoneraefolium WILD). Chin Med. 2014;11(9):21-9. doi: 10.1186/1749-854 6-9-21 